\title{
Constraints Faced by Extension Personnel and Suggestions for Effective Use of ICT
}

\author{
$\operatorname{Rose~Mathews}^{1 *}$ and N. B. Jadav ${ }^{2}$ \\ Department of Agriculture Extension, CoA, JAU, Junagadh, Gujarat, India \\ *Corresponding author
}

\begin{abstract}
A B S T R A C T
The extension personnel are the key role players in providing farm information in interesting and understandable form to farmers. The efficiency with which these information reach farmers determine the level of agricultural productivity. ICT can help extension personnel for effective and timely transmission of technology to farmers. But there are some constraints which prevent the effective use of ICT by extension personnel. Keeping these points in view an attempt has been made to study the profile of extension personnel, constraints faced by them while using ICT and suggestions to overcome the constraints. The study revealed that majority (53.33 per cent) of the extension personnel were middle aged, more than three-fourth (80.00 per cent) were males, exactly three-fourth (75.00 per cent) belonged to rural area, majority (62.50 per cent) had medium achievement motivation, majority (65.84 per cent) had medium level of innovation proneness, majority (60.84 per cent) had medium job commitment, 53.34 per cent had medium level of mass media liveliness, majority (61.67 per cent) had not undergone any training on ICT and 63.33 per cent had medium level of infrastructure facilities. The major constraint experienced by the extension personnel was lack of training on ICT (80.83 per cent). High cost and lack of fund for equipments ranked second followed by lack of farmers interest in ICT based transfer of technology. The most important suggestions given were adequate and timely training on ICT (85.83 per cent). Regular maintenance of already installed equipments (71.67 per cent) and awareness about uses and effectiveness of ICT among various stakeholders (71.67) ranked second and third respectively.
\end{abstract}

Keywords

Constraints, Suggestions, Extension personnel, ICT

\section{Article Info}

Accepted: xx October 2020 Available Online: xx November 2020

\section{Introduction}

Extension personnel have a critical role in the development of farming and farming community. They are the link between scientists, research stations, agricultural universities, policy makers and the farmers. ICT can help the extension agents to ease their extension activities. The application of ICT offers excellent possibilities for strengthening the transfer of technologies between research and extension system and further onward transmission to the end users. But extension personnel are facing many difficulties in the utilization of ICT. So the present study was carried out to find out the constraints faced by the extension personnel while using the ICT and the suggestions offered by them to overcome those constraints. 


\section{Materials and Methods}

The study was conducted in six randomly selected districts of Saurashtra region. 120 extensional personnel were selected proportionately from each district. Structured interview schedule was used for the study.

The respondents were asked to record their constraints and suggestions for the effective use of ICT. The collected data were classified, tabulated, analysed and interpreted to make the finding meaningful.

\section{Results and Discussion}

The results have been discussed in three parts. First part deals with the profile of extension personnel, second part deals with the constraints faced by extension personnel while using ICT, third part deals with the suggestions offered by them to overcome the constraints.

\section{Profile of extension personnel}

The profile of extension personnel given in the Table 1 as the selected characteristics of extension personnel.

The data presented in the Table 1 revealed that more than half (53.33 per cent) of the respondents belonged to middle age category followed by 46.67 per cent in young age category. It was also observed that not a single respondent belonged to old age category.

Majority (80.00 per cent) of the respondents were males and only 20.00 percent were females. It was observed that three-fourth (75.00 per cent) of the respondents belonged to rural area followed by 19.17 per cent belonged to semi-urban area and only 5.83 per cent belonged to urban area. Majority (62.50 per cent) of the respondents belonged to medium level of achievement motivation followed by 22.50 percent belonged to high level of achievement motivation and 15.00 per cent belonged to low level of achievement motivation. Majority (65.84 per cent) of the extension personnel had medium level of innovation proneness followed by 20.83 per cent had low level and 13.33 had high level of innovation proneness respectively.

Majority (60.84 per cent) of the respondents had medium level of job commitment followed by 23.33 per cent had high level of job commitment and 15.83 per cent had low level of job commitment.

More than half (53.34 per cent) of the respondents had medium level of mass media liveliness followed by 25.83 per cent had high level of mass media liveliness and 20.83 per cent had low level of mass media liveliness. Majority (63.34 per cent) of the respondents had medium level of infrastructure facilities followed by 20.83 per cent high level had high level of infrastructure facilities and 15.83 per cent low level of infrastructure facilities.

\section{Constraints faced by extension personnel while using ICT}

The respondents were asked to record the constraints faced by them while using ICT and the obtained data is given in the Table 2 .

It was found that the constraint 'lack of training on ICT' ranked first among the constraints faced by the extension personnel while using ICT.80.83 per cent of the respondents faced this constraint. The constraint high cost and lack of fund for equipments was ranked second which was faced by 74.17 per cent of the extension personnel.

The third rank was to the constraint lack of farmers' interest in ICT based transfer of 
technology which was faced by 64.17 per cent of the respondents. The other constraints faced by the respondents were poor technical know-how (61.67 per cent), lack of motivation to use ICT based extension(57.50 per cent), difficulty in developing content in local language (42.50per cent), slow internet connectivity (26.67 per cent), back ache/ headache/ hand pain (25.83per cent) and adverse effect on eyesight (23.33per cent).

Table.1 Distribution of extension personnel according to their selected characteristics ( $\mathrm{n}=120$ )

\begin{tabular}{|c|c|c|c|}
\hline $\begin{array}{l}\text { Selected } \\
\text { characteristics }\end{array}$ & Category & Frequency & Percentage \\
\hline \multirow[t]{3}{*}{ Age } & $\begin{array}{l}\text { Young (Below } 35 \\
\text { years) }\end{array}$ & 56 & 46.67 \\
\hline & Middle (35-50 years) & 64 & 53.33 \\
\hline & Old (Above 50 years) & 0 & 0.00 \\
\hline \multirow[t]{2}{*}{ Gender } & Male & 96 & 80.00 \\
\hline & Female & 24 & 20.00 \\
\hline \multirow[t]{3}{*}{ Native place } & Rural & 90 & 75.00 \\
\hline & Semi-urban & 23 & 19.17 \\
\hline & Urban & 7 & 5.83 \\
\hline \multirow{3}{*}{$\begin{array}{l}\text { Achievement } \\
\text { motivation }\end{array}$} & Low & 18 & 15.00 \\
\hline & Medium & 75 & 62.50 \\
\hline & High & 27 & 22.50 \\
\hline \multirow{3}{*}{$\begin{array}{l}\text { Innovation } \\
\text { proneness }\end{array}$} & Low & 25 & 20.83 \\
\hline & Medium & 79 & 65.84 \\
\hline & High & 16 & 13.33 \\
\hline \multirow[t]{3}{*}{ Job commitment } & Low & 19 & 15.83 \\
\hline & Medium & 73 & 60.84 \\
\hline & High & 28 & 23.33 \\
\hline \multirow{3}{*}{$\begin{array}{l}\text { Mass } \\
\text { liveliness }\end{array}$} & Low & 25 & 20.83 \\
\hline & Medium & 64 & 53.34 \\
\hline & High & 31 & 25.83 \\
\hline \multirow{5}{*}{$\begin{array}{l}\text { Training } \\
\text { undergone }\end{array}$} & No training & 74 & 61.67 \\
\hline & One training & 17 & 14.17 \\
\hline & Two training & 13 & 10.83 \\
\hline & Three training & 10 & 8.33 \\
\hline & $\begin{array}{l}\text { More than three } \\
\text { training }\end{array}$ & 6 & 5.00 \\
\hline \multirow{3}{*}{$\begin{array}{l}\text { Infrastructure } \\
\text { facilities }\end{array}$} & Low & 19 & 15.83 \\
\hline & Medium & 76 & 63.34 \\
\hline & High & 25 & 20.83 \\
\hline
\end{tabular}


Table.2 Constraints faced by extension personnel while using ICT $(n=120)$

\begin{tabular}{|c|c|c|c|c|}
\hline Sr. No. & Constraints & Frequency & Percentage & Rank \\
\hline 1. & Poor technical know how & 74 & 61.67 & V \\
\hline 2. & High cost and lack of fund for equipments & 89 & 74.17 & II \\
\hline 3. & Lack of training on ICT & 97 & 80.83 & I \\
\hline 4. & Poor infrastructure facilities & 76 & 63.33 & IV \\
\hline 5. & Back ache/headache/hand pain & 31 & 25.83 & $\mathrm{X}$ \\
\hline 6. & Adverse effect on eyesight & 28 & 23.33 & IX \\
\hline 7. & $\begin{array}{l}\text { Lack of farmers interest in ICT based } \\
\text { transfer of technology }\end{array}$ & 77 & 64.17 & III \\
\hline 8. & Slow internet connectivity & 32 & 26.67 & VIII \\
\hline 9. & $\begin{array}{l}\text { Difficulty in developing content in local } \\
\text { language }\end{array}$ & 51 & 42.50 & VII \\
\hline 10. & $\begin{array}{l}\text { Lack of motivation to use ICT based } \\
\text { extension }\end{array}$ & 69 & 57.50 & VI \\
\hline
\end{tabular}

Table.3 Suggestions offered by extension personnel for the effective use of ICT $(n=120)$

\begin{tabular}{|c|c|c|c|c|}
\hline Sr. No. & Suggestions & Frequency & Percent & Rank \\
\hline 1. & $\begin{array}{l}\text { Awareness about the uses and effectiveness of ICT } \\
\text { among various stakeholders }\end{array}$ & 86 & 71.67 & III \\
\hline 2. & Adequate and timely training on ICT & 103 & 85.83 & I \\
\hline 3. & $\begin{array}{l}\text { Enough fund should be provided for ICT facilities } \\
\text { and services }\end{array}$ & 58 & 48.33 & IV \\
\hline 4. & $\begin{array}{l}\text { Maintenance of already installed equipments should } \\
\text { be regular }\end{array}$ & 101 & 84.16 & II \\
\hline 5. & $\begin{array}{l}\text { Uninterrupted power and internet facility should be } \\
\text { ensured }\end{array}$ & 32 & 26.67 & V \\
\hline 6. & $\begin{array}{l}\text { Selection of ICT tools should be proper, location } \\
\text { specific and need based. }\end{array}$ & 30 & 25.00 & VI \\
\hline
\end{tabular}

Suggestions offered by extension personnel for the effective use of ICT

Suggestions for the effective utilization of ICT were collected from the respondents and are listed in the Table 3.

The most important suggestion given by the extension personnel was that adequate and timely training on ICT should be given. It was suggested by 85.83 per cent of the respondents.

The suggestion maintenance of already installed equipements should be regular ranked second among the suggestions. This suggestion was given by 84.16 per cent of the respondents.

Awareness about the uses and effectiveness of ICT among various stakeholders ranked third among the suggestions. It was offered by 71.67 per cent of the respondents.

The other suggestions given by the respondents were enough fund should be provided for ICT facilities and services (48.33 per cent) followed by uninterrupted power and internet facility should be ensured by 26.67 per cent of the respondents and 
selection of ICT tools should be proper, location specific and need based (25.00 per cent).

In conclusion the ICT offer a wide opportunity in the agricultural extension field. But the extension personnel are facing various difficulties while using them. Lack of training on ICT is the major constraint recorded by the extension personnel followed by high cost and lack of fund for equipments and lack of farmer's interest in ICT based transfer of technology. Among the suggestions offered adequate and timely training on ICT ranked first followed by regular maintenance of already installed equipments and awareness about the uses and effectiveness of ICT among various stakeholders.

\section{References}

Agha, N.; Ghanghas, B. S. and Chahal, P. K. 2018. Use of Information and Communication Technology by extension personnel to disseminate agricultural information. International Journal of Current Microbiology and
Applied Sciences, 7(4): 1369-1376.

Chithra, G. 2015. Strategies for capacity building of extension personnel for using information technologies. M. Sc. (Agri.) Thesis (Unpublished), KAU, Kerala.

Khamoushi, S. and Gupta, J. 2014. Factors encouraging ICT usage by agricultural extension scientists in North India. Journal of Agricultural Extension and Rural Development, 6(4): 132-137.

Sharma, R. 2018. Utilization pattern of Information and Communication Technologies (ICT) among scientists of KVKs in Madhya Pradesh and Chhattisgarh. Ph. D. Thesis (Unpublished), RVSKVV, Gwalior.

Sireesha, P; Rao, B. S. and Raju, Thammiraju, D. 2014. Areas of utilization of information and communication technology (ICT) tools by various Animal Husbandry (A.H.) Organizations in Andhra Pradesh. International Journal of Innovative Research in Science, Engineering and Technology, 3(5): 12063-12072.

\section{How to cite this article:}

Rose Mathews and Jadav, N. B. 2020. Constraints Faced by Extension Personnel and Suggestions for Effective Use of ICT. Int.J.Curr.Microbiol.App.Sci. 9(11): 9-13. doi: https://doi.org/10.20546/ijcmas.2020.911.002 